\title{
LX. Physical and geological observations on the principal Geysirs of Iceland
}

\section{A. Descloizeaux}

To cite this article: A. Descloizeaux (1847) LX. Physical and geological observations on the principal Geysirs of Iceland, Philosophical Magazine Series 3, 30:203, 391-409, DOI: 10.1080/14786444708645417

To link to this article: http://dx.doi.org/10.1080/14786444708645417

册 Published online: 30 Apr 2009.

Submit your article to this journal

Џ Article views: 11

Q View related articles $₫$ 
The resistances of wires are to each other directly as their lengths, and inversely as the products of their sections and conductibilities. If the wire of the galvanometer helix be as above, 1000 inches in length and $\frac{1}{10} 0^{d t h}$ of an inch in cliameter, then eight inches of wire $d$, being of platinum, onesixteenth of an inch in diameter, and having, suppose, one-fifth of the conducting power of copper, will equal in resistance about an inch and a quarter of the helix wire; therefore since $r=1000$ and the greatest value of $w=1 \frac{1}{4}$, the quantity $\frac{w r e^{\prime}}{r+w}$ cannot in this instrument be of any importance in the determination of resistances, and may always be safely neglected. For the accurate measurement, with an instrument having finer wires, of resistances offered to weaker forces, the fraction may be useful.

LX. Physical and Geological Obscrvations on the principal Geysirs of Iceland. By A. Descloizeaux*.

IN Iceland the name of Geysir is generally given to a jet1 ting thermal spring, and the names of hver (cauldron) and laug (baths) are applied to springs simply bubbling up, or wholly tranquil, contained in basins almost always regular, circular or elliptic.

The jetting springs most celebrated on account of their volume, the beauty of their eruptions, and the importance of the deposits which they have formed and which they still form at the present day, are those known by the names of the Great Geysir and Strokkur. Although most of the travellers who have visited Iceland have described the eruptions of these two springs which they witnessed, and of which some have published pretty accurate representations, I will here relate the manner in which this phænomenon takes place.

In the Great Geysir, whose waters, as I shall observe bereafter, have formed for themselves a very regular basin in the form of a truncated cone hollowed at the summit, the eruptions are preceded by subterraneous detonations, which have always been justly compared to a distant sound of artillery, and which powerfully shake the base and lateral parts of the cone. After each detonation, the column of water which occupies the central channel is upraised, in the form of a hemisphere, some metrest above the surface of the basin; then all becomes calm again.

These detonations and these upliftings of the liquid mass are produced pretty regularly every two hours, as we have

* Translated from the Amn. de Chim. et de Phys. for April 1847.-The Icelandic orthography has been preserved in this memoir.

$\uparrow$ The metre is equivalent to about 3 feet $3 \frac{3}{8}$ inches, $-T_{R}$. 
ascertained by a series of observations carried on for several days, and consequently they are far from announcing a great eruption; but when this is approaching, detonations stronger and more frequent than the first are heard, the uprisings of the central column become more and more considerable, and all at once an immense column of water, three metres in diameter at its base, is projected into the air to a height varying from thirty to fifty metres, spreads like a fountain at its summit, and falls again in part into the large reservoir, eighteen metres in diameter, which forms the basin of the spring; the rest of the mass of water flows over the external sides of the cone, and spreads out into the little rills which furrow the plateau on which this cone rests. The column of water does not generally attain its greatest height until several consecutive jets at very short intervals have prepared the observer for the magnificent spectacle which the Geysir: reserves for the close of the eruption, like a skilful firework-maker who terminates his exhibition by a splendid bouquet. These eruptions last from five to seven minutes.

In the Strokkur, the circumstances attending the eruption are a little different, and the form of the channel which discharges the emitted waters is doubtless the principal cause which gives the phænomenon a peculiar character. In this channel, which represents a well even with the ground, the water is at about three metres below the surface, and it boils up with incessant oscillation. When it is attempted to produce an artificial eruption by covering the surface of the water with clods of earth or turf, or when a natural eruption is about to take place, this boiling ceases for some instants, and a pointed, lanceolate jet issues suddenly to a certain height; it is soon followed by another, which is in its turn succeeded by a series of slender columns, very pointed at the summit, with serrated outlines, which cannot be better compared than to immense yew-trees. These columns, which succeed one another sometimes for twelve to fifteen minutes, attain various heights, which reach, as in the Geysir, to fifty metres. When the eruptions of the Strokkur take place naturally, the jetting water is quite as limpid as that of the Geysir; and, if the weather is calm and the sun bright, nothing can exceed the magnificence of these immense columns of clear water, perfectly vertical, and reflecting the brilliant colours of the rainbow. If however the Strokkur is excited by clods of earth or turf, the water is coloured black, often of a very deep tinge, and the phænomenon loses much of its splendour.

Before passing to the results of the thermometric experiments and the various observations made at the Geysir and 
the Strokkur, I shall describe in a summary manner the topographical and geological position of these two springs, for the geological portion of the Voyage en Islande of the Scientific Commission of the North contains extensive details upon this subject.

The two principal geysirs of Iceland are situated in the south-east part of the island, at eighty-seven kilometres, in a straight line, to the east-north-east of Reykjavík, and at fortysix kilometres to the north-west of Hecla. These fountains, accompanied by a great number of hvers and laugs, occupy a space of 500 metres from north to south, by 100 metres from east to west, towards the northern part of a large plateau of volcanic tufa, bordered on three sides by large glaciers or Jökulls, the principal of which are, - on the north, the LángJökull; on the north-east, the Hofs-Jökull and the ArnarfellsJökull; on the east, the Skaptár-Jökull; on the south, Hecla and the Torfa-Jökull.

This vast plateau is traversed, from north-east to southwest, by two of the largest rivers in Iceland, the Hvítá and the Thjórsá, and by their numerous tributaries: these two principal rivers, which take their sources, the first in the snows of the Láng-Jökull, and the second at the foot of the Arnarfells-Jökull, flow into the sea at the south-west part of the plateau, which is terminated on this side by low sandy shores. At numerous points of the plateau containing the geysirs, rise mountains which have in many instances the form of isolated cones, composed of a conglomerate, the chief constituent of which is basalt and a brown tufa, the principal element of which appears to be the mineral which Sartorius von Waltershausen found in the ancient tufas of Etna, and which he has named palagonite. The height of these mountains, several of which have preserved the appearance of craters of eruption, and still present, on their slopes or at their base, debris of streans of lava, does not exceed 500 to 600 metres.

Beside these cones, we meet with some hillocks of a gray phonolite, inclosing numerous crystals of felspar, and very small crystals of pyroxene: some strips of ancient trap or compact basalt, often divided into columns, appear also at the surface of the plateau; and a sort of vitreous pitchstone, both green and reddish, which appears to have resulted from the fusion of the phonolite by the basalt, is ordinarily seen in contact with these two rocks.

The hill nearest to the geysirs, from which it is distant only about 360 metres, to the west, consists of upheaved and almost vertical strata of a bluish gray phonolite, nuch 
disintegrated on the lower part, where it presents numerous traces of having been acted upon and undergone a slight alteration by the thermal waters, but it is tenacious and tolerably homogeneous towards the summit. The height above the plain of this hill, which has the name of Laugafjall, may be estimated at seventy-five metres. From the foot of its eastern escarpment, an undulating district extends for a length of about 350 metres, entirely conposed of ancient siliceous concretions, slightly altered and friable. This district, the highest hills of which rise to nearly twenty-five to thirty metres' elevation above the plain, is pierced with a multitude of holes, from which steam and the vapour of sulphuretted hydrogen still escape; small quantities of alum and sulphur are deposited on the edges of some of these holes, one of which is situated at the very foot of the trachytic hill.

The existence of an ancient siliceous district, so extensive as that which $I$ have just mentioned, certainly appears attributable to numerous extinct geysirs, the abundant deposits of which have at length completely stopped the orifices from which their eruptions took place. The lower part of this ancient district is separated from the deposits of the present Great Geysir by a small ravine of two metres in depth, situated at ten metres from the basin of the geysir, and directed nearly from south to north. The sides of this ravine, from whence acid vapours are also disengaged at several points, discloses both in the ancient and modern formation, numerous layers of siliceous concretions of a very varied aspect, distributed in the midst of a bolary clay in which the red colour predominates.

On the right side which bounds the deposits of the present geysir, and in a very plastic clay, we meet with small stems of birch-trees, of the size of those which still grow in the country, entirely silicified and converted into chalcedony; the clay itself is full of small crystals of white pyrites, formed from the iron which it contains and of the sulphur of the vapour springs. Above the chalcedonous stems, and approaching the most recent strata of concretions, we now only find birch-leaves and a network of herbaceous plants, forming a sort of siliceous travertine. In this same part, and always in the middle of a reddish clay, I have observed a thin, very regular, and extensive layer of zoned chalcedony; this sulstance, which is translucid as long as it remains immersed in the moist clay, becomes opake and of an enamel white by a simple desiccation in the open air, without being able to re-acquire its transparency, even on a prolonged immersion.

The banks of the little river the Beíná, which flows at 300 
metres to the east of the Geysir, and into which a part of the water that overflows after each eruption run, present a fact of the same kind: in the midst of a network of silicified plants forming several layers, the total thickness of which exceeds three metres, we found small portions of silex, which possessed all the properties of precious opal, as long as they are strongly hydrated, but which only preserve their vivid colours while they remain immersed in water, or are kept from drying. May ve not hence conclude that the opals and chalcedonies of some ancient volcanic districts owe their origin to phænomena similar to those of the present geysirs of Iceland?

The left side of the small ravine spoken of above, which bounds the deposits of the ancient extinct geysirs, did not present chalcedonous wood, but we extracted from it birch stems transformed into very friable white silica, which appeared to have been derived from individuals larger than those we meet with at the present day in Iceland. Some specimens of these woods, in which the cells and vessels may still be observed under the microscope, are penetrated in various directions with small roots which appear to belong to the same species; we might without doubt thence conclude that the large stems were already in a state of advanced decomposition when the silica came and penetrated into their tissue, - - a circumstance which would perhaps explain the reason why these woods have not been converted into chalcedony, but into pulverulent silica.

It is at all events certain that a birch-wood once existed between the ancient and recent geysirs; and, as these trees cannot live where the soil is covered with siliceous concretions, it must be admitted that these two classes of fountains did not exist simultaneously, and that the recent geysirs succeeded the primitive geysirs, when the orifices of these last became insufficient to give a passage to the masses of water which had to be cast forth *.

With respect to the duration of the ancient phænomena, the depth of twenty. five metres at least of the soil which they have formed, shows that it must have been very considerable. In fact, the concretions deposited by the present geysirs have not yet exceeded a thickness of four to five metres; and all seems to prove that, within the historical period of Iceland, the increase of this thickness, which is distributed over an extended surface, has been very small, so that we must attribute a very high antiquity to the recent geysirs themselvest.

* A very detailed description of the districts formed by the ancient and recent geysirs has been given by $M$. Robert in the geological part of the Voyage of the Northern Scientific Commission to Iceland.

$\dagger$ As it is almost impossible, in order to prove the thickness of deposits 


\section{M. Descloizeaux's Physical and Geological Observations}

The two jetting springs, the temperatures of which I have principally sought to determine during my stay in that locality with M. Bunsen of Marburg, are the Great Geysir and the Strokkur. I shall first direct my remarks to the Great Geysir.

The only observations of any accuracy which we hitherto possessed on the temperature of this spring are those of M. Lottin, a member of the Northern Scientific Commission, who visited Iceland in 1836; but these observations left much still to be desired, both from the method itself which M. Lottin followed, and from the experiments not having been sufficiently repeated to embrace the various phases of the moments of calm and of eruptions of the geysir. The determinations which $\mathrm{M}$. Bunsen and $I$ have made were taken immediately before a great eruption, inmediately after that eruption, and in the interval of two great consecutive eruptions. The thermometers which I employed were doublebulbed, and constructed by Bunten after the directions of $M$. Regnault*: they were composed of a small cylindrical reservoir, surmounted by a stem of accurate calibre, and divided into parts of equal capacity; this stem ended in a finely drawnout point terminating almost at the summit of a small cap of thin glass, soldered to the top of the stem, at the part where its diameter began to diminish, and containing a small excess of mercury.

In taking observations with these thermometers, the stem was entirely filled with mercury, at the ambient temperature; it was then immersed, by the side of a good standard, in a bath, the temperature of which was nearly constant, and lower than that which was to be observed: a portion of the mercury of the stem was raised into the small upper bulb. When the mercury was stationary and occupied exactly the extremity of the small drawn-out point, the temperature of the standard formed in a given time, to establish at the Geysir itself a fixed mark capable of resisting the ignorant curiosity of certain visitors, I endeavoured to construct one easy to be recognised only by the forewarned and attentive eye. For this purpose, I chose two contiguous laugs, situated at nearly an equal distance from the Strokkur and the Geysir, proceeding towards the Laugafjall : the most northern laug, without apparent overflow, is contained in a nearly elliptical basin, the major axis of which is seven metres, the minor one $3^{\mathrm{m} \cdot 40}$, and the depth $2^{\mathrm{m}} \cdot 55$; the temperature at the surface was found to be $98^{\circ} \cdot 5$. The second laug, separated only from the first by a small natural wall, has a more irregular basin, of a depth of $9 \mathrm{~m} \cdot 30$, and the water of which, indicating a temperature of $96^{\circ} \cdot 5$, flows off incessantly by a small rivulet which passes near the Strokkur, depositing on its way abundantincrustations. In the narrowest part of the wall which separates these two laugs I made an aperture, the successive obliteration of which it will always be easy to ascertain. The following were the dimensions of this aperture on Jily 12th, 1846 :-Depth $0 \mathrm{~m} \cdot 065$; length, from east to west, $0 \mathrm{~m} \cdot 260$; breadth, from north to south, $0 \mathrm{~m} \cdot 110$.

* See Scientific Memoirs, Part XVI. p. 588 . 
was noted; the thermometer, inclosed in a copper or iron case, the lid of which was hermetically closed by means of a screw and red-lead cement, was let down into the spring; after remaining there thirty minutes, it was raised and compared again with the standard; the mercury stopped at a certain division of the stem, and the quantity of mercury which had escaped from the stem during the observation, converted into centigrade degrees and added to the first temperature indicated by the standard, gave the temperature of the spring. The thermometers employed by $\mathbf{M}$. Bunsen were constructed upon the same principle; only that, instead of a capsule soldered to the upper part of the stem, the capillary opening of the latter was closed by a small point of iron, kept vertical by means of a spring, which the mercury could raise, so as to fall over into the case.

In each of the five experiments which we made at the Great Geysir, we employed five thermometers arranged on a single line, and separated by nearly equal intervals.

It is known that the Great Geysir has formed by successive incrustations a very regular basin, having the shape of a truncated cone, the exterior slopes of which have a mean inclination of $8^{\circ}$, whose summit is occupied by a cup or vase*, presenting only on the edges some small clefts through which is carried the overilow of the water, when its level rises. The mean inclination of the sides of this cup is $13^{\circ}$.

In the centre of the basin is a circular well, which appears perfectly regular as far as the eye can discern. Between two consecutive eruptions, this well and the cup which surrounds it are completely filled with water, a very small portion only of which overflows after the upheavings, which take place about every hour and half : but immediately after the great eruptions, the cup is completely empty, and in the well the water descends below the bottom of the cup from one metre to $2^{\mathrm{m}} \cdot 50$, according as the projected column had attained a greater or less height; the former level is not restored until after six or seven hours.

'The following are the principal dimensions which we have found for the different parts of the Geysir:-

Diameter of the basin or cup, on the edges, from north to south

Diameter of the basin or cup, in a perpendicular direction . . . . . . . . . . 1800

Diameter of the central well . . . . . . 3.00

* Sir W. J. Hooker thus describes it:-“To compare great things with small, the shape of this basin resembles that of a saucer with a circular hole in its middle." Tour in Iceland, p. 117.- $\mathrm{T}_{\mathrm{R}}$. 


\section{M. Descloizeaux's Physical and Geological Observations}

Depth of the well, including that of the basin :- $m$

1. In the direction of the first diameter . . . 23.50

2 . In the direction of the second diameter . . $21 \cdot 50$

Depth of the cup in the centre . . . . . . 1.57

As we took care, in each experiment, to alter the order of our thermometers, that their indications might be checked, I shall indicate by numbers and by the letter $B$ those of $M$. Bunsen, and by the letter $\mathrm{D}$ those which belonged to me.

It will be conceived that the temperature at the surface of the water which fills the basin must be excessively variable; for that temperature depends at the same time on the temperature of the sides of the basin, on that of the air, on the force and direction of the wind, and on the hygrometric state of the atmosphere, which allows of a more or less speedy evaporation. This is the reason why the numbers given by different travellers, for the temperature of the water on the edge of the basin, agree so little; we ourselves made a series of observations, the terms of which differ considerably among themselves. They are as follow:-

1846.

h $m$

Temp. at the margin.

3rd July, at 1030 A.M.; basin filled . $86^{\circ} 0$ centigrade.

3rd July, at 1058 A.M.; Id. . . . 89.0

3rd July, at 1130 A.M. ; Ill. . . . 88.0

3rd July, at 325 P.M.; $1 d$. . . . $89 \cdot 7$

4th July, at 1235 P.M.; Id. . . . $76^{\circ} 0$

4th July, at 117 P.M.; Id. . . . $85^{\circ} 0$

9 th July, at 150 P.M. ; basin half-full 82.5 in the wind.

9th July, at 150 P.M.; Id. . . . $86^{\circ} 0$ under the wind.

We will admit that the mean temperature of the water at the surface and in the centre of the basin is $85^{\circ} \mathrm{C}$.

The following table indicates the temperatures found in different points of the liquid column, immediately before a great eruption :-

\begin{tabular}{|c|c|c|c|}
\hline \multicolumn{2}{|c|}{$\begin{array}{l}\text { Third Experiment. } \\
\text { The } 7 \text { th July, at } 2^{\mathrm{h}} 55^{\mathrm{m}} \text { in the after- } \\
\text { noon : four hours before a great } \\
\text { eruption. Basin filled : total depth, } \\
23^{\mathrm{m}} \cdot 50 \text {; length of the line, } 22^{\mathrm{m}} \cdot 85 \text {. }\end{array}$} & \multicolumn{2}{|c|}{$\begin{array}{l}\text { Fourth Experiment. } \\
\text { The 7th July, at } 6^{\mathrm{h}} 58^{\mathrm{m}} \text { in the after- } \\
\text { noon: ten minutes before a great } \\
\text { eruption. Basin filled : total depth, } \\
23^{\mathrm{m}} \cdot 50 \text {; length of the line, } 22^{\mathrm{m}} \cdot 85 \text {. }\end{array}$} \\
\hline 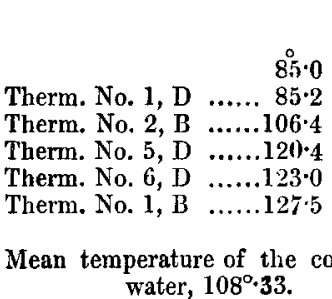 & $\begin{array}{c}\text { Heights. } \\
\text { m } \\
22 \cdot 85 \\
19 \cdot 55 \\
14 \cdot 75 \\
9 \cdot 85 \\
5 \cdot 00 \\
0 \cdot 30 \\
\text { 3ottom. } \\
\text { mn of }\end{array}$ & $\begin{array}{l}\text { Therm. No. 5, D .....84.7 } \\
\text { Therm. No. 1, B } \ldots \ldots .110 \cdot 0 \\
\text { Therm. No. 6, D .....121.8 } \\
\text { Therm. No. 1, D without result. } \\
\text { Therm. No. 2, B ......126.5 }\end{array}$ & \begin{tabular}{r}
\multicolumn{1}{c}{} \\
$22 \cdot 85$ \\
$19 \cdot 55$ \\
$14 \cdot 75$ \\
$9 \cdot 85$ \\
$5 \cdot 00$ \\
$0 \cdot 30$ \\
Bottom. \\
amn of
\end{tabular} \\
\hline
\end{tabular}


The mean temperature of the column of water was obtained by multiplying half the sum of the indications of two consecutive thermometers, by the interval which separates them, and dividing the sum of all these prodiucts by the sum of the intervals, or the length of the line.

Twelve minutes after the fourth experiment, at $7^{\mathrm{h}} 40^{\mathrm{m}}$ in the evening, the great eruption took place.

The following are the results of the fifth experiment commenced the $7 \mathrm{th}^{\mathrm{July}}$, at $9^{\mathrm{h}} 45^{\mathrm{m}}$ in the evening, two hours after the great eruption; basin half-filled: height of the liquid column, $22^{\mathrm{m} \cdot 75}$; length of the line, $22^{\mathrm{m} \cdot} \cdot 50$. Heights.

\begin{tabular}{|c|c|c|}
\hline & $85^{\circ} \cdot 0$ & $22 \cdot 50$ \\
\hline Thermometer No. 1, D & .103 .0 & $13 \cdot 50$ \\
\hline Thermometer No. 3, D & $.121 \cdot 0$ & $9 \cdot 70$ \\
\hline Thermometer No. 5, D & lost & $4 \cdot 90$ \\
\hline Thermometer No. $6, \bar{D}$ & $.122 \cdot 5$ & $0 \cdot 30$ \\
\hline
\end{tabular}

Bottom.

Mean temperature of the column of water $108^{\circ} 83$.

The three preceding tables show, in an evident manner, that the mean temperature of the column of water which fills the central well of the Great Geysir, remaining in other respects constant, the distribution of the temperature, in different points of that column, varies with the moment when the observation was made. We see, on examining these tables, that there is at the bottom of the well a maximum, immediately before the eruptions, which may be estimated at $127^{\circ}$; and a minimum, immediately after, which may be estimated at $123^{\circ}$.

The results given in the two following tables, obtained at different periods between two consecutive eruptions, show that the phænomenon always passes in the same manner, and with tolerable regularity:-

\begin{tabular}{|c|c|c|c|}
\hline \multicolumn{2}{|c|}{$\begin{array}{l}\text { First Experiment. } \\
\text { The 6th July, at } 0^{\mathrm{h}} 30^{\mathrm{m}} \text { in the morn- } \\
\text { ing : three hours after a great erup- } \\
\text { tion, and eleven hours before the } \\
\text { following eruption. Basin half-full: } \\
\text { height of the liquid column, } 22^{\mathrm{m}} \cdot 75 \text {. }\end{array}$} & \multicolumn{2}{|c|}{$\begin{array}{l}\text { Second Experiment. } \\
\text { The 6th July, at } 8^{\mathrm{h}} 20^{\mathrm{m}} \text { in the morn. } \\
\text { ing: nine hours after a great erup- } \\
\text { tion, and twenty-three hours before } \\
\text { the following ernption. Basin filled: } \\
\text { height of the column, } 23^{\mathrm{m} \cdot 50} \text {; } \\
\text { length of the line, } 22^{\mathrm{m}} \cdot 85 \text {. }\end{array}$} \\
\hline 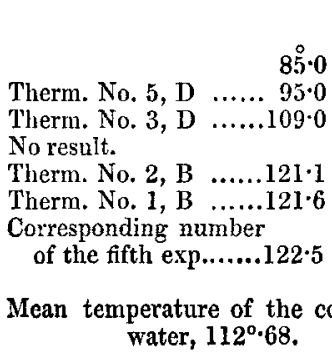 & \begin{tabular}{|c|} 
Heights. \\
$\mathrm{m}$ \\
$22 \cdot 50$ \\
$19 \cdot 70$ \\
$16 \cdot 30$ \\
$12 \cdot 90$ \\
$9 \cdot 50$ \\
$6 \cdot 00$
\end{tabular} & $\begin{array}{l} \\
\text { Therm. No. 6, D } \ldots . .885^{8 \cdot 0} \\
\text { Therm. No. 5, D } \ldots \ldots .85 \cdot 8 \\
\text { Therm. No. 2, B } \ldots \ldots .113 \cdot 0 \\
\text { Therm. No. 3, D } \ldots \ldots .122 \cdot 7 \\
\text { Therm. No. 1, B } \ldots \ldots .123 \cdot 6\end{array}$ & \begin{tabular}{|} 
Heights. \\
$\mathrm{m}$ \\
$22 \cdot 85$ \\
$19 \cdot 20$ \\
$14 \cdot 40$ \\
$9 \cdot 60$ \\
$4 \cdot 80$ \\
$0 \cdot 30$ \\
Bottom.
\end{tabular} \\
\hline
\end{tabular}




\section{M. Descloizeaux's Physical and Geological Observations}

Thus, notwithstanding the relative lightness of the most heated water, which tends to rise to the surface, we see that, even after the eruptions, the temperature of the different strata does not become equalized; still further, in proportion as the inferior strata become heated, to reach their maximum, the upper strata become cool, undoubtedly in consequence of evaporation, and of the heat communicated to the sides of the well and the basin; so that the greatest difference of temperature at the two extreme levels corresponds precisely to the moment of the eruptions.

We can now ascertain what would be the boiling-point of water submitted to a pressure equal to that of the atmosphere, augmented by the liquid column the height and mean temperature of which we have determined in our five experiments. For this purpose, we must first express the pressure of this liquid column in millimetres of mercury at $0^{\circ}$. The density of the water of the Geysir, found at from 1.0010 to $10^{\circ}$ centigrade; the curve which represents the results obtained by M. Isidore Pierre for the dilatation of distilled water, and which I admit as being applicable to the water of the Geysir, extending it up to $113^{\circ}$; lastly, the density of the mercury at $0^{\circ}$, compared to that of distilled water at $4^{\circ}$, and found at 13.596 by M. Regnault, enables us to make this reduction. We thus find that the heights of the columns of water in our different experiments correspond, in millimetres of mercury at $0^{\circ}$, to the following numbers :-

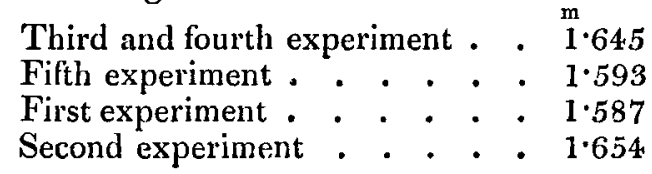

From the equations

$$
\log e=a-b \alpha^{x}, \quad x=t-100^{\circ},
$$

and from the data

$$
\log a=1.9977641, \quad \log b=0.4692291, \quad a=5.8267890 \text {, }
$$

laid down by $\mathrm{M}$. Regnault, in which $e$ represents the tension of steam at saturation, expressed in millimetres of mercury, and $x$ the temperature to which that pressure corresponds, we can derive the value of $x$ and of $t$; and this last quantity will precisely represent the boiling-point of water submitted to the pressures

$$
\begin{array}{ll}
0 \cdot 760+1^{\mathrm{m}} \cdot 645, & 0 \cdot 760+1^{\mathrm{m}} \cdot 593, \\
0 \cdot 760+1^{\mathrm{m} \cdot} \cdot 587, & 0 \cdot 760+1^{\mathrm{m} \cdot} \cdot 654 .
\end{array}
$$


The corresponding values of $t$ are as follow :-

Third and fourth experiment . . . $t=136^{\circ} 151$

Maximum temperature at the bottom 127

Difference . . $\overline{9^{\circ} \cdot 151}$

Fifth experiment . . . . . . $t=135^{\circ} \cdot 398$

Minimum temperature at the bottom $\frac{122^{\circ} \cdot 5}{12^{\circ} \cdot 898}$
Difference . .

First experiment . . . . . . $t=135^{\circ} \cdot 31$

Temperature at the bottom . . . $122^{\circ} \cdot 5$

Difference . . $\overline{12^{\circ} \cdot 81}$

Second experiment . . . . . $t=136^{\circ} \cdot 28$

Temperature at the bottom $\cdot$. $\quad 123^{\circ} \cdot 60$

Difference . . $\overline{12^{\circ} \cdot 68}$

Thus, at the point to which the lower thermometer can penetrate, the water does not attain the temperature of ebullition which it should have under the pressure to which it is subjected; but it approaches that temperature in proportion as a great eruption is near. We may thence conclude that the centre of heat which raises the temperature of the water of the Geysir is situated at a certain distance below the presumed bottom of the central well, and we may deduce from this a plausible explanation of the manner in which the eruptions are determined.

Let us in fact suppose that the column of water in the central basin communicates, by a long and sinuous channel, with the space, be it what it may, which receives the direct action of the subterranean heat: after an eruption during which a projection of a great quantity of water and vapour has taken place, the lower parts of the liquid mass are cooled, and the steam which is formed in the reservoir submitted to the action of the heat has a less tension than that at which the weight of the central column and that of the atmosphere are in equilibrium ; this vapour, as it forms, becomes condensed in contact with the water which fills the sinuous channel, and it imparts to that water its latent heat. The increase of temperature of the water of the channel is transmitted by degrees to the lower part of the central column where the thermometer can reach; but this increase is retarded by the atmospheric air and the other gases which accompany the vapour; however, at the lapse of a shorter or longer time, the water of the channel must boil, and the steam which continues to form cannot longer condense there; this vapour must therefore accumulate, and acquire a gradually increasing tension, until this Phil. Mag. S.3.Vol.30. No. 203. June 184.7. 2 E 


\section{M. Descloiseaux's Physical and Geological Observations}

tension is able to overcome the resistance of the column of water which fills the basin, and to project it into the air.

A thermometer placed at four metres above the bottom of the central well during an eruption which took place July 14, 1846 , at $3^{\mathrm{h}} 15^{\mathrm{m}}$ in the morning, and which raised the column of water to $49^{\mathrm{m}} \cdot 37$, according to a measurement taken by $M$. Waltershausen, indicated a temperature of $124^{\circ} \cdot 24$, which corresponds perfectly to what would have been found at the same point in the third and fourth experiments.

In the intervals of the great eruptions it often happens that the column of water is raised to one metre, or $1^{\mathrm{m}} \cdot 50$ above the usual level, and it is easy to conceive that it must be thus; for, if the vapour formed in the subterranean reservoir is not condensed entirely at its contact with the water of the sinuous channel of which $I$ have spoken, and if it is accompanied with a sufficient quantity of atmospheric air, or of other gases, it must in the end divide the liquid column, and escape at the surface, producing those subterranean detonations and those jets which all travellers have remarked. A fact worthy of attention is, that these detonations appear to be produced periodically with sufficient regularity; whereas the great eruptions only take place at quite unequal intervals, as is shown by the following table of a series of observations which we continued for several days. This difference might be explained by admitting that the production of vapour is not perfectly regular. In the following table, the three columns indicate the date of the observations, the hours when the detonations or jets took place, and those when great eruptions were produced :-

\begin{tabular}{|c|c|c|c|c|c|}
\hline $\begin{array}{l}\text { Dates of the } \\
\text { Observations. }\end{array}$ & $\begin{array}{l}\text { Explosions } \\
\text { and great } \\
\text { Eruptions. }\end{array}$ & $\begin{array}{l}\text { Dates of the } \\
\text { Observations. }\end{array}$ & $\begin{array}{c}\text { Explosions } \\
\text { and great } \\
\text { Eruptions. }\end{array}$ & $\begin{array}{l}\text { Dates of the } \\
\text { Observations. }\end{array}$ & $\begin{array}{l}\text { Explosions } \\
\text { and great } \\
\text { Eruptions. }\end{array}$ \\
\hline 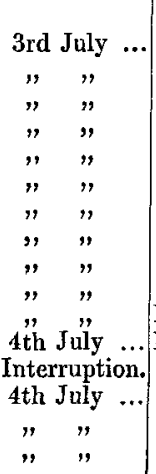 & $\begin{array}{rrr}\mathrm{h} & \mathrm{m} \\
9 & 45 & \text { a.m. } \\
10 & 58 & \mathrm{a} . \mathrm{m} . \\
12 & 15 & \text { p.m. } \\
1 & 5 & \text { p.m. } \\
2 & 5 & \text { p.m. } \\
3 & 25 & \text { p.m. } \\
4 & 0 & \text { p.m. } \\
8 & 0 & \text { p.m. } \\
8 & 25 & \text { p.m. } \\
9 & 55 & \text { p.m. } \\
10 & 48 & \text { p.m. } \\
12 & 14 & \text { a.m. } \\
& & \\
6 & 0 & \text { a.m. } \\
7 & 50 & \text { a.m. } \\
9 & 7 & \text { a.m. }\end{array}$ & 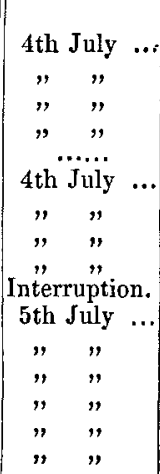 & 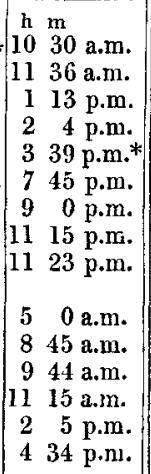 & 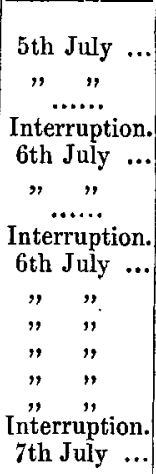 & 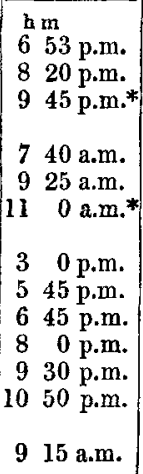 \\
\hline
\end{tabular}

- The great eruptions are denoted by an *. 
Table (continued).

\begin{tabular}{|c|c|c|c|c|c|}
\hline $\begin{array}{l}\text { Dates of the } \\
\text { Observations. }\end{array}$ & $\begin{array}{l}\text { Explosions } \\
\text { and great } \\
\text { Eruptions. }\end{array}$ & $\begin{array}{l}\text { Dates of the } \\
\text { Observations. }\end{array}$ & $\begin{array}{l}\text { Explosions } \\
\text { and great } \\
\text { Eruptions. }\end{array}$ & $\begin{array}{l}\text { Dates of the } \\
\text { Observations. }\end{array}$ & $\begin{array}{l}\text { Explosions } \\
\text { and great } \\
\text { Eruptions. }\end{array}$ \\
\hline 7th July & 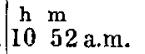 & 10th July. & $\begin{array}{ll}\mathrm{h} & \mathrm{m} \\
12 & 45 \text { p.m. }\end{array}$ & Interruption. & \\
\hline$" \quad "$ & 130 p.m. & , , " & 210 p.m. & 12th July. & 557 p.m. \\
\hline & 253 p.m. & & 330 p.m. & $" \quad$, & p.m. \\
\hline$"$ & 330 p.m. & " & 424 p.m. & & 855 p.m. \\
\hline$"$ & $\begin{array}{lll}5 & 40 & \text { p.m. } \\
7 & 40 & \text { p.m. }\end{array}$ & $"$ & $\begin{array}{l}50 \text { p.m. } \\
715 \text { p.m. }\end{array}$ & $\begin{array}{l}\text { Interruption. } \\
\text { 13th July ... }\end{array}$ & \\
\hline & 1050 p.m. & & 933 p.m. & 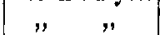 & 648 a.m. \\
\hline & 1110 p.m. & Interruption & & $"$ & \\
\hline Interruption. & 1135 p.m. & $11 \mathrm{tl}$ & 330 a.m. & $"$ & $40 \mathrm{a.m}$. \\
\hline 8th July ... & 30 a.m. & Interruption. & & $"$ & $\begin{array}{rr}9 & 52 \text { a.m. } \\
11 & 7 \text { a.m. }\end{array}$ \\
\hline$" \quad "$ & 420 a.m. & llth July... & 830 a.m. & $"$ & 1128 a.m. \\
\hline$"$ & $\begin{array}{ll}6 & 10 \\
8 & 27\end{array}$ & $"$ & 95 & & 123 \\
\hline & 10 16 a.m. & Interruption. & 113 & $\begin{array}{l}\text { Interruption. } \\
\text { 13th July... }\end{array}$ & 347 p.m. \\
\hline & 1235 p.m. & 11th July.. & 146 p.m. & Inter & \\
\hline nterruption. & & & 335 p.m. & 13th & 645 \\
\hline iption. & $\begin{array}{llll}10 & 45 & \text { a.m.* }\end{array}$ & & $\begin{array}{lll}4 & 35 & \text { p.m. } \\
6 & 10 & \text { p.m.* }\end{array}$ & & $\begin{array}{ll}753 \\
9 & 12\end{array}$ \\
\hline 9th July & 325 p.m. & Interruption. & & & 947 \\
\hline & 545 p.m. & 12th July... & 55 a.m.* & " & 105 \\
\hline$"$ & $\begin{array}{ll}725 \\
92\end{array}$ & Interruption. & & Into & 1143 p.m. \\
\hline Interruption. & & , & $10 \quad 45$ a. & 14th July... & 315 a.m.* \\
\hline $\begin{array}{l}\text { 10th July } \\
\text { Interrupti }\end{array}$ & $8 \quad 0$ a.n & $"$ & $\begin{array}{rrr}12 & 55 & \text { p.m. } \\
2 & 50 & \text { p.m. }\end{array}$ & $\begin{array}{l}\text { Interruption. } \\
\text { 15th July... }\end{array}$ & $9 \quad 0$ a.m.* \\
\hline
\end{tabular}

The heights of the two most remarkable eruptions during our visit to the Geysir, measured by M. Sartorius von Waltershansen with a theodolite, gave-

The 6th of July, at $11^{\mathrm{h}} 00^{\mathrm{m}}$ A.M., 145 French ft. $=47^{\mathrm{m}} \cdot 101$. The 14th of July, at $3^{\mathrm{h}} 15^{\mathrm{m}}$ A.M., 152 French $\mathrm{ft} .=49^{\mathrm{m}} \cdot 375$.

I have said, at the commencement of this memoir, that the water, when it had completely left the basin, after the great eruptions, descended into the central well, at about $2^{\mathrm{m}} \cdot 50$ below its orifice. The following are two numbers I observed:-

The 11 th of July, at 6 o'clock in the evening, a depth of water below the orifice of the well . . . . . $2^{\mathrm{m} \cdot 00}$ The 14th of July, at $3^{\mathrm{h}} 15^{\mathrm{m}}$ in the morning $\dagger .2^{\mathrm{m} \cdot 60}$

* The great eruptions are denoted by an *.

$\dagger$ If we calculate the quantity of water which, to produce this lowering, escaped from the basin, during and after the eruption, to flow almost wholly into the Beiná, we find that this quantity was, in the first case, $157^{\mathrm{mc}} \cdot 585$, and, in the second case, $161^{\mathrm{mc} \cdot} \cdot 825$ : now, admitting that at $135^{\circ} .8$ and under the pressure of three atmospheres, the steam has a volume equal to 600 times that of the water which produced it, and a density of 0.0016145 , a quantity of vapour represented by 94,551 cubic metres $=152,652$ kilogrammes in the first case, and by 97,095 cubic 
$I$ also availed myself of my visit to the Geysir to make some chemical experiments upon the water of this remarkable spring, which it would have been difficult to render so conclusive with water carried to Paris. I paid particular attention to the estimation of the sulphuretted hydrogen, the odour of which is very perceptible in the vapour which incessantly escapes from the basin, and to ascertain whether the soda contained in that water is in the caustic or carbonated state.

The sulphydrometer of $M$. Dupasquier served me for the first determination. On operating with necessary caution, I found that one litre of water of the Geysir, perfectly limpid and cooled, protected from contact with the air, to about $40^{\circ}$, contained $2^{\mathrm{ec}} \mathbf{4 4 8}$ of sulphuretted hydrogen.

To ascertain the state of the sodn, we collected some water in a well-stoppered bottle, acidulated it with some drops of hydrochloric acid, and boiled it; the vapour, collected in some lime-water, yielded a very perceptible precipitate. Mixed with some ammoniacal chloride of calcium, the water was not rendered perceptibly turbid; it therefore does not contain free carbonic acid.

The presence of chlorine or of alkaline chlorides was likewise ascertained by means of nitrate of silver.

To obtain a complete analysis of this water, I collected a quantity in a flask with a drawn-out neck and closed it over the lamp, and in glass bottles closed with a good cork stopper covered with caoutchouc.

The water of the first flask was employed to estimate the carbonic acid combined with the soda; this determination was made in the laboratory of the Val-de-Grâce, where $M$. Millon was kind enough to place at our disposal one of the apparatus which he employs to estimate the carbonic acid in organic analysis. A second operation, made comparatively on water of the bottles closed with a caoutchouc stopper, gave a result nearly identical with that of the first experiment.

metres $=156,760$ kilogrammes in the second case, on condensing upon the lower part of the Geysir, might re-establish its primitive level.

I have stated above that this level was re-established in about seven hours, and that from that moment only a small quantity of water flowed over after each of the detonations which took place every two hours.

The deficit in the Geysir, after a great eruption, might therefore be made good by a subterraneous disengagement of vapour, varying from 1807 kilogrammes to 2394 kilogrammes an hour. Now an ordinary steamengine, without coating or covering and working without pressure (sans enveloppe et sans détente, consuming five kilogrammes of pit-coal an hour, expends about thirty kilogrammes of vapour by horse-power. We see therefore that the present phænomenon of the Geysir requires for its production, only a development of vapour corresponding to nearly that of an engine of 700 horse-power, which gives an approximate idea of the order of this phænomenon. 
M. Damour kindly undertook the analysis of the residue which this water leaves on evaporation, and $I$ here transcribe only the results which he has given in a separate notice. A litre of this water, evaporated at $65^{\circ}$ centigrade, gives a residue weighing 1.3900 gr., and effervescing with acids. Heated to $300^{\circ}$, the weight of this residue was reduced to $1 \cdot 1830$; and at a cherry-red heat the residue aggintinates, and now amounts to only 1.0540 .

The same quantity of water contains, -

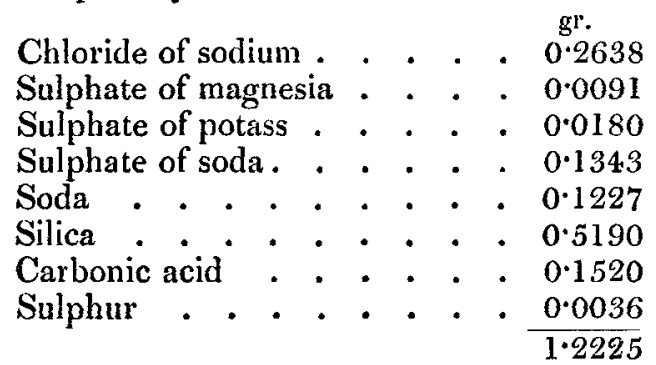

The quantities of oxygen of the silica and the bases are in the following relation:-

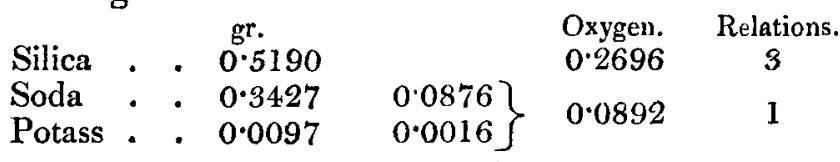

On subtracting from the weight of the alkalies the quantity necessary to saturate the chlorine and the sulphuric acid, there remains,-

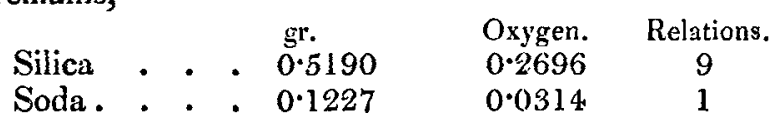

In several analyses, M. Damour found that the relation 3: 1 between the oxygen of the silica and that of the bases was constant, and he concluded therefrom that the silica is probably dissolved first in the water of the Geysir, in the state of alkaline silicates, $\mathrm{NaO}, \mathrm{SiO}^{3}, 3 \mathrm{NaO}, 2 \mathrm{SiO}^{3}$, which can be produced artificially, and which are very soluble in water; then, by the action of the sulphurous and hydrochloric vapours, sulphates and chlorides are formed: the quantity of alkali combined with the silica undergoes a successive reduction, and the primitive relation of $3: 1$ becomes $9: 1$. In this state of saturation, a portion of the silica ceases to be soluble, and is deposited, without doubt, in a quantity corresponding to the amount of alkali saturated every day by the action of the vapour springs, and consequently of the 

oxidation of the alkaline sulphurets in contact with the atmosphere.

We can conceive that the water of the Geysir, passing into the state of vapour at a very high temperature in subterranean conduits formed by felspathic rocks, attacks their sides, and is thus charged with the salts which the analysis discovers in it.

Beside the analysis of the water of the Geysir, the memoir of M. Damour contains those of several of the springs of Reykir, on the south coast of the island, and that of the water of Laugarnes, situated at a short distance from Reykjavík. All these waters are alkaline and siliciferous; and, although the proportions of the substances which they contain are different in each, they offer, like that of the Geysir, a constant relation between the oxygen of the silica and that of the bases: only, the thermal springs of Reykir deposit, like the Geysir, numerous siliceous concretions, whilst that of Laugarnes forms none at all. The experiments of M. Damour explain this difference very well; for in the waters of Reykir, the constant relation between the oxygen of the silica and that of the bases is as $2: 1$; and after subtracting the quantity of alkalies necessary to saturate the chlorine and sulphuric acid, this relation becomes as $8: 1$. In this state of saturation, a part of the silica ceases to be soluble and is deposited.

In the water of Laugarnes, on the contrary, the primitive relation of the quantities of oxygen is as $3: 1$, as for the Geysir, and this relation, after the saturation of the chlorine and the sulphuric acid, becomes as $6: 1$, numbers which represent an alkaline silicate entirely soluble in water.

\section{Strokkur.}

The Strokkur, the Icelandic name of which, signifying churn, well indicates the continual movement of the water in the channel which contains it, is situated at about sixty metres to the south of the Great Geysir. It has not, like the latter, formed itself a regular and conical basin; the waters occupy a sort of level well, the edges of which are only encircled by a rounded mound, and worn by the frequent passage of the waters.

The dimensions of this channel are as follows:-

Total depth below the surface . . . $13^{\mathrm{m} \cdot 55}$

Diameter of the opening . . . . . . $2^{\mathrm{m} \cdot 40}$

Diameter at $8^{\mathrm{m} \cdot} \cdot 30$ below the surface . . $0^{\mathrm{m} \cdot 26}$

The channel of this second jetting spring is therefore irregular, and its diameter diminishes rapidly from the surface to 
the bottom. The level of the water, which generally stands at rather above three metres below the ground, falls principally after great eruptions, but it sometimes rises suddenly; and the surface of the water is incessantly boiling.

The following are some observations I made upon these oscillations :-

8 th July, at $4^{\text {h }} 30^{\mathrm{m}}$ P.M.: depth below the surface . ${ }^{\mathrm{m}} \cdot 40$

91h July, at 11 o'clock A.M. : after a great eruption . 4.22

9th July, after a second eruption, immediately after

the first . . . . . . . . . . . . . 4.55

9th July, at 3 o'clock P.M.: Strokkur calm; depth . 3.35

9th July, at $4^{\mathrm{h}} 15^{\mathrm{m}}$ P.M. : after a great eruption . . $4 \cdot 40$

9th July, at $4^{\text {h }} 59^{\mathrm{m}}$ P.M. : Strokkur calm . . . . $4 \cdot 40$

9th July, at $5^{\text {h }} 32^{\mathrm{m}}$ P.M. : Id. . . . . . . . . $3 \cdot 05$

9th July, at $7^{\mathrm{h}} 15^{\mathrm{m}}$ P.M.: Id. . . . . . . . . 350

10th July, at $6^{\mathrm{h}} 57^{\mathrm{m}}$ P.M. : $I d$. . . . . . . . 355

To determine the temperature of this column of water, we employed the same thermometers as at the Great Geysir; but we only arranged three on a line. The following are the results obtained in these three experiments:-

\begin{tabular}{|c|c|c|c|}
\hline \multicolumn{2}{|c|}{$\begin{array}{l}\text { First Experiment. } \\
\text { 8th July, at } 4^{\mathrm{h}} 38^{\mathrm{m}} \text { P.M.: height of } \\
\text { the column of water above the } \\
\text { bottom, } 10^{\mathrm{m}} \cdot 15 \text {. }\end{array}$} & \multicolumn{2}{|c|}{$\begin{array}{l}\text { Second Experiment. } \\
9 \text { th July, at } 5^{\text {h }} 32^{\mathrm{m}} \text { P.M., an hour after } \\
\text { a great eruption : height of the } \\
\text { columan of water above the bottom, } \\
10^{\mathrm{m} \cdot 50 \text {. }}\end{array}$} \\
\hline $\begin{array}{c}\text { Therm. No. } 1, \text { D..... } 10080 \\
\text { Therm. No. 3, B..... } 111.4 \\
\text { Therm. No. 8, B..... } 112.9 \\
\text { Mean temperature of the co } \\
\text { water, } 104^{\circ} \cdot 77 .\end{array}$ & $\begin{array}{c}\text { Heights. } \\
\mathrm{m} \\
10 \cdot 15 \\
6 \cdot 00 \\
3 \cdot 00 \\
0 \cdot 30 \\
\text { Bottom. } \\
\text { umn of }\end{array}$ & 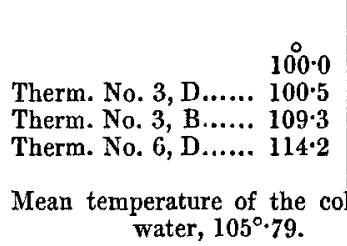 & $\begin{array}{c}\text { Heights. } \\
\text { m } \\
10 \cdot 50 \\
9 \cdot 20 \\
6 \cdot 20 \\
2 \cdot 95 \\
\text { Bottom. } \\
\text { lumn of }\end{array}$ \\
\hline
\end{tabular}

Third Experiment.

loth July, at $6^{\mathrm{n}} 57^{\mathrm{m}}$ P.M., six hours after a great eruption : height of the column of water above the bottom, 10 metres.

\begin{tabular}{|c|c|}
\hline $\begin{array}{l}\text { Thermometer No. 3, D ..................... } \\
\text { Thermometer No. 3, B .................... } 113 \\
\text { Thermometer No. 6, D ................... } 113\end{array}$ & $\begin{array}{c}\text { Heights. } \\
\mathrm{m} \\
10 \cdot 00 \\
8 \cdot 85 \\
4.65 \\
0.35 \\
\text { Bottom. }\end{array}$ \\
\hline
\end{tabular}

Mean temperature of the column of water, $105^{\circ} \cdot 278$.

From the water bubbling incessantly at the surface, we 
always supposed that its temperature there was that of boiling water; the second and third experiments show, in fact, that at one metre below the surface it is so. Lastly, a thermometer placed at the bottom of the channel during an eruption, indicated a temperature of $115^{\circ} \mathrm{C}$.

We see that the column of the water of the Strokkur possesses, at different heights, much more constant temperatures than those of the Geysir, and that the influence of the eruptions is very little felt; this depends evidently on the continual boiling of the water, which determines incessantly ascending currents in the column-and a sort of intermixture. The mean height of the column of water of the Strokkur is equal to a column of mercury at $0^{\circ}$, of $0^{\mathrm{m}} \cdot 7 \mathrm{l} 79$.

The temperature at which the water, submitted to this pressure and to that of the atmosphere, would begin to boil, is $120^{\circ} .043$.

We have seen that the maximum temperature at the bottom of the Strokkur was $115^{\circ}$; the difference between this maximum and the point of ebullition of the water is therefore $5^{\circ} \cdot 043$. This number is sensibly smaller than the corresponding number found at the Great Geysir, which may be owing to the point attained by the thermometer in the Strokkur being nearer to the subterranean source of heat, or to the channels which form the communication between the liquid column and that central point being narrower; the heat parted with by the vapour condensed to the water of this channel is transmitted more rapidly to the base of the column.

The eruptions of the Strokkur, which are quite as high as those of the Great Geysir, instead of presenting, like the latter, the appearance of a beautiful fountain with a base three metres in diameter, and a crown of about eighteen metres, present only an ensemble of sharp, jagged points, resembling very tall and slender yew-trees. In the Geysir, the eruptions always take place naturally; at the Strokkur, on the contrary, they are either natural or artificial. All travellers in fact have remarked that, if the orifice of the Strokkur is filled with light stones or pieces of earth and grass, the oscillations of the water cease for some instants; then, at the end of five or ten minutes, a jet of a blackish water charged with earth is shot out to a great height, and is followed by other intermitting jets during eight to ten minutes. This experiment, which can be repeated several times a day with success, seems to prove that the small excess of pressure resulting from the accumulation of clods of earth upon the water suffices to hinder the normal disengagement of the vapour through the column of water, and to augment the tension of that which 
is formed in the subterranean reservoir, to the extent of producing a sudden detonation.

$\mathrm{Be}$ this as it may, as we desired to know whether the natural eruptions of the Strokkur were produced more regularly than those of the Geysir, and had any connexion with them, we only forced the eruptions twice at our arrival, and we noted, in the following table, all the great natural eruptions:-

\begin{tabular}{|c|c|c|}
\hline Dates. & $\begin{array}{c}\text { Forced } \\
\text { Eruptions. } \\
\text { Heights. }\end{array}$ & $\begin{array}{c}\text { Natural } \\
\text { Eruptions. } \\
\text { Hours. }\end{array}$ \\
\hline 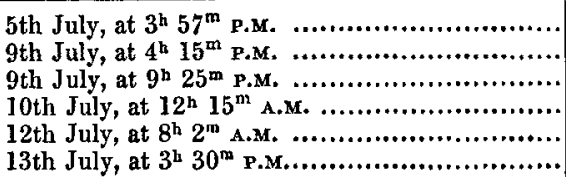 & 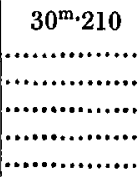 & $\begin{array}{c}49^{\mathrm{m} \cdot 375} \\
43^{\mathrm{m} \cdot 528} \\
\text { not measured. } \\
\text { not measured. } \\
47^{\mathrm{m} \cdot 426}\end{array}$ \\
\hline
\end{tabular}

It will be seen from this table that the natural eruptions of the Strokkur do not present more regularity than those of the Geysir, and that their coincidence with the latter, if it sometimes happens, is not general.

Some observers have admitted that there was a direct communication between the Strokkur and the Geysir: unfortunately I was not able, during my visit, to collect water from the Strokkur sufficiently freed from the earthy matters coming from the clods of earth which we threw upon it during the first days of our arrival, to bring it back and submit it to an accurate analysis; but the quantity of sulphuretted hydrogen, which I found to be $1^{\text {cc. }} 748$ per litre, differs sufficiently from that which the water of the Geysir contains, to allow us to conceive that these two springs, subjected perhaps to the same cause of subterranean heat, are not, as has been thought, in immediate connexion.

LXI. On the existence of a New Vegeto-Alkali in GunCotton. By Robert Porrets, Esq.*

A $\mathrm{T}$ the last meeting of this Society on the 7 th instant, a joint $A$ communication from Mr. Teschemacher and myself "On the Chemical Composition of Gun-Cotton" was read $t$, and in the last paragraph but one thereof I suggested that a view

* Communicated by the Chemical Society; having been read Dec. 21, 1846.

$\uparrow$ This communication will be found at p. 273 of the present volume of this Journal. 